\title{
The genetic relationship for Klebsiella pneumoniae isolated from human urinary tract and beef
}

\author{
S.F. Klaif", H.H. Naser and J.N. Sadeq \\ College of Veterinary Medicine, University of AL-Qadisiyah, Al-Qadisiyah, Iraq, "email: sabafk28@yahoo.com
}

(Received May 18, 2018; Accepted July 22, 2018)

\begin{abstract}
The present study aimed to describe the genetic relationships of zoonotic characterization of Klebsiella pneumoniae isolated from Human urinary tract and beef. The study includes (50) urine samples from human and (50) beef samples. The isolation and identification of Klebsiella pneumonia were done by using enrichment culture method and Vitek 2, then confirmed by PCR technique based on $16 \mathrm{~S}$ ribosomal RNA gene which designed in this study using NCBI-GenBank (LT599801.1) and DNA sequencing was done on some positive isolates. The results show that Klebsiella pneumoniae was isolated from beef at $38(76 \%)$ and from human at $32(64 \%)$ by vitek2. The PCR technique was show highly sensitive and specific confirmative detection of Klebsiella Pneumonia isolates at Clarify DNA sequencing of a partial sequence of $16 \mathrm{~S}$ ribosomal RNA gene was shown homology sequence identity highly with NCBI-Blast Klebsiella pneumoniae isolates. The phylogenetic analysis was show clear genetic similarity at ( 0.5 genetic change) between human and beef in Klebsiella pneumoniae isolates. The gene sequence deposited into NCBI-GenBank accession numbers (MF314450.1, MF314451.1, MF314452.1, MF314453.1). In conclusion, the study presents the first report in Iraq of genetic relationship among $K$. pneumoniae isolates from beef and humans. Therefore, it is essential to define the role of animals as an important source for the distribution of pathogen related to public health.
\end{abstract}

Keywords: Klebsiella pneumonia, 16s rRNA, Polymerase change reaction, phylogenetic tree Available online at http://www.vetmedmosul.com

$$
\begin{aligned}
& \text { العلاقة الوراثية لجرثومة الكلبيسيلا الرئوية والمعزولة من الجهاز البولي في الإنسان والأبقار } \\
& \text { صبا فلاح كليف، حسن حاجم ناصر، وجنان ناظم صادق } \\
& \text { كلية الطب البيطري، جامعة القادسية، القادسية، العراق }
\end{aligned}
$$

الدر اسة الحالة تهدف العلاقة الور اثية للأهمية المشتركة للكليبسلا الرئوية التي تصيب الجهاز البولي للانسان ولحوم الأبقار . تضمنت الإنه

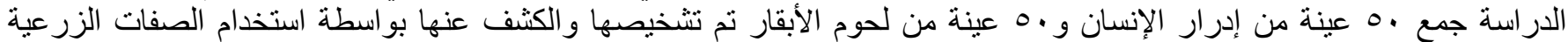

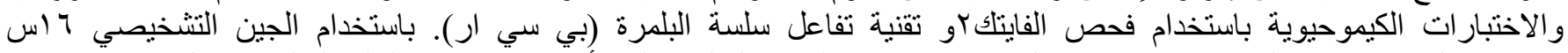

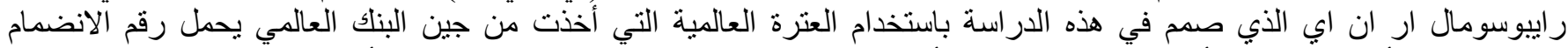

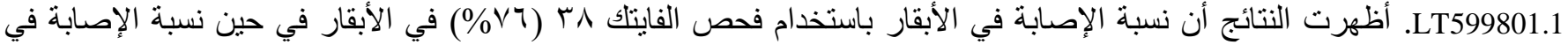

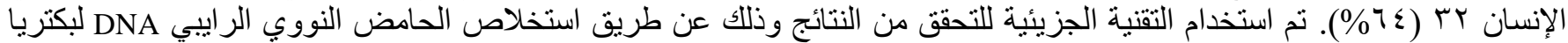

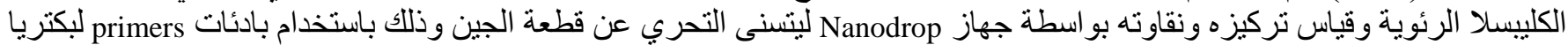

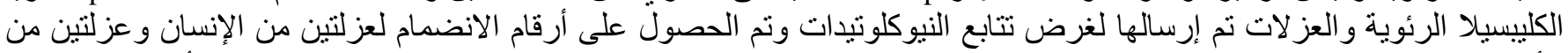

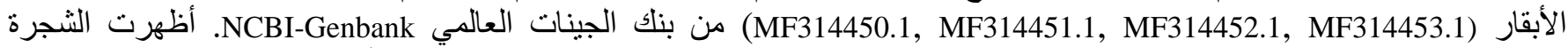
الور اثية تشابه بنسبة (9 9 \% ـ - . (\%) مع العزلات العالمية لكلييسل الرئوية المعزولة من الإنسان و الأبقار ـ الخلاصة ,الدراسة الحالية 


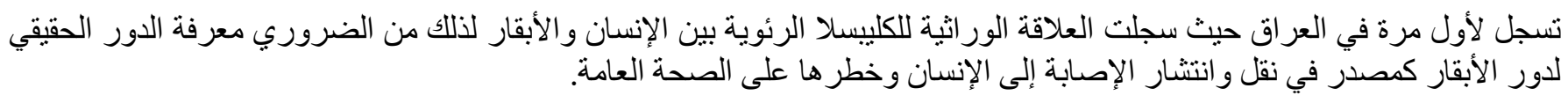

\section{Introduction}

Klebsiella pneumoniae is a gram-negative bacterium that cause a liver abscess, bacteremia, pneumonia that is transmitted among hospital in Asia and the Middle East (1$3)$. In previous years, $K$. pneumoniae are known infectious pneumonia. Also, it causes Friedlander syndrome that associated with diabetic people $(1,2)$.

Diabetic Mellitus summarize its pathogenesis can cause changing in mucosal immunity. Also causes serious of changes in normal flora also In the Europe and US, $K$. pneumoniae usually associated with antibiotic resistance that provided in the hospital. Also causes 6-17\% of infection of the urinary tract, 3-20\% all neonatal septicemia, $4-17 \%$ infections in intensive care units, $2-4 \%$ wound infections, $7-14 \%$ pneumonia, $6-17 \%$ infection of the urinary tract, $4-15 \%$ septicemia, $4-17 \%$ infections in intensive care units (4-9).

Klebsiella pneumoniae is opportunistic bacteria in animals and human and causes contamination in the meat (10). Also, K. pneumoniae causes diseases in horses and cows $(11,12)$. In humans, $K$. pneumoniae can invade intestine and results in intestinal disease (13). Klebsiella pneumoniae causes many diseases such as meningitis, wound infections cystitis, liver abscess, bacteremia, pyelonephritis, osteomyelitis and septicemia, as well as pneumonia $(13,14)$.

The aim of study is investigating the relationship of $K$. pneumoniae isolated from beef and infection of $K$. pneumoniae in human samples which isolated from urine by using polymerase chain reaction, sequencing and phylogenetic tree by using housekeeping gene 16s rRNA.

\section{Material and method}

\section{Sample collection}

Fifty urine samples were collected from human suffering from a urinary infection in Al-Diwanyah teaching hospital, and also fifty beef samples were collected from the different market in Al-Diwaniyah. All samples transported to microbiology laboratory in Veterinary Medicine College for bacterial isolation and identification. All samples were used for isolation of $k$. pneumoniae by culturing on MacConkey and blood agar plates and incubated for 24 hours at $37^{\circ} \mathrm{C}$ according to standard procedure (15). The isolates were activated by inoculated on CHROMagar Orientation and incubated at $37^{\circ} \mathrm{C}$ for overnight, Identification of isolates based on the morphology of colonies and by biochemical tests according to (16). The Vitek 2 biochemical reaction test was performed for identification klebsiella pneumoniae isolates.

\section{DNA extraction of bacteria genome}

Fresh bacterial genomic DNA of $K$. pneumoniae was extracted from $1 \mathrm{ml}$ nutrient broth samples in $1.5 \mathrm{ml}$ microcentrifuge tubes by using (Presto TM mini g DNA Bacteria Kit, Geneaid - China), the extract gDNA was checked by nanodrop spectrophotometer and store in deep free until usage.

\section{Polymerase chain reaction (PCR)}

PCR reaction which used for detection $K$. pneumonia by using housekeeping gene (16s rRNA). The housekeeping gene of Klebsiella pneumoniae -16s rRNA, gotten from NCBI GenBank Klebsiella pneumoniae strain K-18, F(GGAACTGAGACACGGTCCAG) and R (CCAGGTAAGGTTCTTCGCGT) from NCBI- GenBank with accession number (LT599801.1) complete genome with product sizes of $660 \mathrm{bp}$.

Preparation of PCR master mix is done according to (Bioneer. Korea). Master mix of the PCR consist of $\left(\mathrm{MgCl}_{2}\right.$ $1.5 \mathrm{mM}$, dNTPs $250 \mu \mathrm{M}, \mathrm{KCl} 30 \mathrm{mM}$, Taq DNA polymerase $1 \mathrm{U}$, Tris- $\mathrm{HCl}(\mathrm{pH}$ 9.0) $10 \mathrm{mM}$, stabilizer, and the stain). The reaction was done by adding DNA template $(5 \mu \mathrm{l}),(1.5 \mu \mathrm{l})$ forward and reverse primer (10 pmole) to mixture tube of PCR then complete the volume to reach (20 $\mu \mathrm{l})$. Then mixed by vortex (Bioneer company. Korea). The reaction was done in PCR thermocycler apparatus (Mygene Bioneer company, Korea). The operation is done by setting up the initial denaturation for five minutes at $\left(94^{\circ} \mathrm{C}\right) .30$ cycle is a total cycle of denaturation at $94^{\circ} \mathrm{C}$ for 30 second, annealing for 30 second at $60^{\circ} \mathrm{C}$, and extension for 30 seconds at $72^{\circ} \mathrm{C}$. the last stage is extension stage for ten minutes at $72^{\circ} \mathrm{C}$. All final products tested by electrophoresis apparatus 1.5\% Agarose gel and stained with $3 \mu \mathrm{l}$ ethidium bromide. The buffer which used in electrophoresis apparatus is Tris-borate- EDTA (TBE) (boric acid $5.5 \mathrm{~g}$, Tris-base $10.8 \mathrm{~g}$, EDTA (pH 8) $4 \mathrm{~mL}$ at $(\mathrm{pH}$ 8) (the mixture combined and shaken for complete dissolving). The DNA ladder that used in this study consist of 100-1500-base pair that made in the USA in Roche Company. Aliquots $(10 \mu \mathrm{l})$ of PCR products were applied to the gel. A constant voltage for 1 hour was used for product separation. The Ethidium bromide used in the study as the stain of DNA then test under UV transilluminator light (UVItec, Paisley, UK). 


\section{DNA sequencing method}

DNA sequencing method was performed for confirmative detection of $k$ pneumoniae strain, two isolates were taken from human and two from cattle based on $16 \mathrm{~s}$ $r R N A$ gene, the PCR product was purified from agarose gel by using (EZ EZ-10 Spin Column DNA Gel Extraction Kit, Biobasic, Canada). The purified 16s rRNA gene in PCR product samples was sent to Bioneer Company in Korea for performed the DNA sequencing using ( $\mathrm{AB}$ DNA sequencing system) (17).

The genomic sequences were assembled and submitted in GenBank- NCBI then multiple sequence alignment was done by Basic local alignment Search Tool (BLAST) for phylogenetic tree construction and phylogenetic analysis by using the MEGA6 program.

\section{Results}

\section{Isolation and identification of Klebsiella pneumoniae}

The isolation of $K$. pneumoniae from human urine and beef was illustrated in table 1. Pink, mucoid, lactose fermented colonies were considered to be Klebsiella spp on MacConkey agar while on orientation medium, colonies are metallic blue colour, large, rounded (Figure 1). Further biochemical tests were done for confirmation of the isolates (Table 2).

\section{Detection of $K$. pneumoniae}

After culturing of the isolates, these isolates were positive produce for VATEK2 for biochemical tests from 50 isolates $38(76 \%)$ positive for beef meet cattle while from 50 human urine isolates $32(64 \%)$ positive in vitek2 (Table 3).

\section{Molecular Identification of K. pneumoniae}

The positive isolates of vitek 2 biochemical tests are produced for confirmative endpoint PCR for detection $16 \mathrm{~s}$ rRNA gene (671bp) of Klebsiella pneumonia in Ethidium bromide-stained agarose gel using specific primers and the ladder in size (100-1500bp), 16 (50\%) human urine isolates from different regions gave positive results (line 1-8) (Figure 2) (Table 4).

While cattle beef meat isolates gave $21(55 \%)$ from different region of meat source line (8-15) (Figure 2) (Table 4). The comparative results by VITEK2 and PCR technique shown in (Figure 3). In addition to the confirmative diagnosis of the Klebsiella, the PCR products used in the sequencing for analysis of $16 \mathrm{~s} r R N A$ gene of a predominant strain of Klebsiella pneumonia in Iraq.

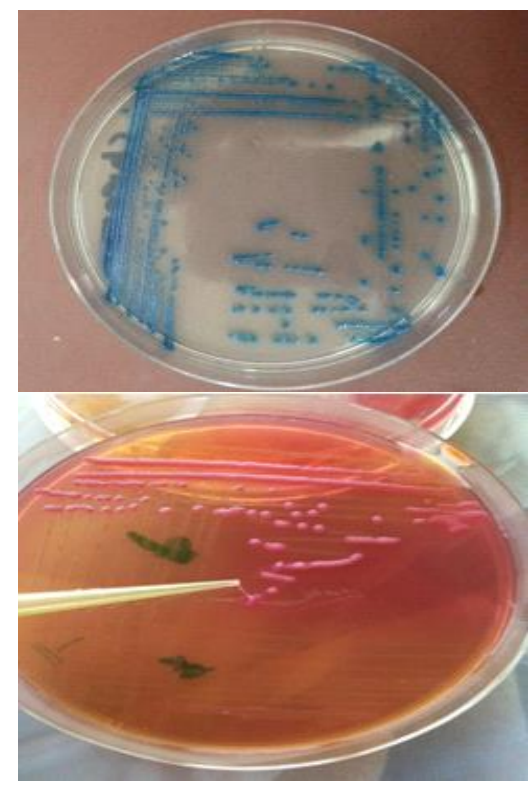

Figure 1: Klebsiella pneumonia on CHROM agar Orientation, produce metallic blue, rounded and large colonies, Klebsiella pneumonia on MacConkey agar characteristic by (rounded, mucoid, large and pink colonies).

Table 1: Cultural characters of Klebsiella pneumoniae on culture media

\begin{tabular}{lll}
\hline $\mathrm{N}$ & Culture media & Cultural characters for Klebsiella pneumoniae \\
\hline 1 & MacConkey agar & rounded, mucoid, large and pink colonies \\
2 & Eosin methylene blue & Purple, large, mucoid colonies \\
3 & CHROM agar Orientation & metallic blue, mucoid, rounded and large colonies \\
\hline
\end{tabular}

Table 2: The result of the biochemical tests for Klebsiella Pneumonia which isolated from human and animal

\begin{tabular}{lll}
\hline $\mathrm{N}$ & Biochemical test & Result of Biochemical test \\
\hline 1 & Triple sugar Irion Test & A/A-GAS - NO $\mathrm{H}_{2} \mathrm{~S}$ \\
2 & Indole Test & Positive (red color Ring appear in the top of the test tube) \\
3 & Citrate Utilization Test & Positive (The green colors converted to blue) \\
\hline
\end{tabular}

$\mathrm{A}=$ acid $\mathrm{H} 2 \mathrm{~S}=$ Hydrogen sulfide 
Table 3: K. pneumoniae number and their isolation percentages of from cattle and human samples vitek2

\begin{tabular}{lccc}
\hline $\begin{array}{l}\text { Type of } \\
\text { sample }\end{array}$ & \multicolumn{2}{c}{ Klebsiella pneumoniae } & \multirow{2}{*}{ Total } \\
\cline { 2 - 3 } & Positive & Negative & \\
\hline $\begin{array}{l}\text { Beef meat } \\
\text { of cattle }\end{array}$ & $38(76 \%)$ & $12(24 \%)$ & $50(100 \%)$ \\
$\begin{array}{l}\text { Urine samples } \\
\text { from Human }\end{array}$ & $32(64 \%)$ & $18(36 \%)$ & $50(100 \%)$ \\
\hline
\end{tabular}

Table 4: K. pneumoniae number and their isolation percentages of from cattle and human samplesF by PCR technique

\begin{tabular}{lccc}
\hline $\begin{array}{l}\text { Type of } \\
\text { sample }\end{array}$ & \multicolumn{2}{c}{ Klebsiella pneumoniae } & Total \\
\cline { 2 - 3 } & Positive & Negative & \\
\hline $\begin{array}{l}\text { Beef meat } \\
\text { of cattle }\end{array}$ & $21(55 \%)$ & $17(45 \%)$ & $38(100 \%)$ \\
$\begin{array}{l}\text { Urine samples } \\
\text { from Human }\end{array}$ & $16(50 \%)$ & $16(50 \%)$ & $32(100 \%)$ \\
\hline
\end{tabular}

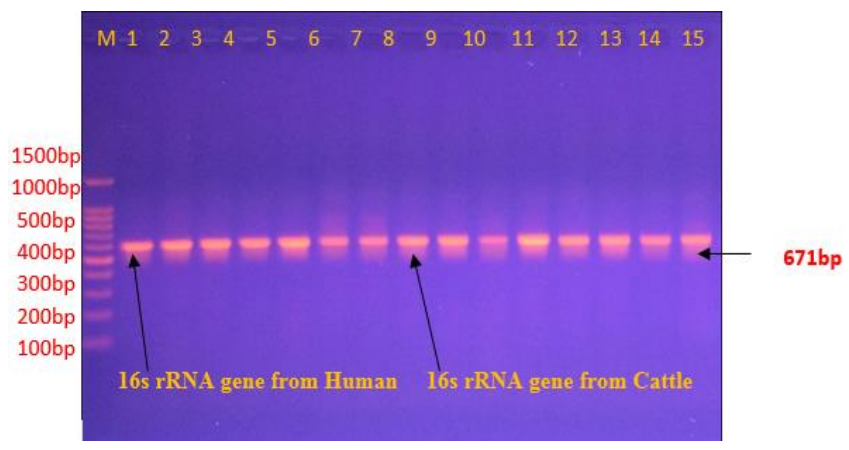

Figure 2: Agarose gel electrophoresis of $K$. pneumoniae stained with Ethidium bromide and product size $671 \mathrm{bp}$.

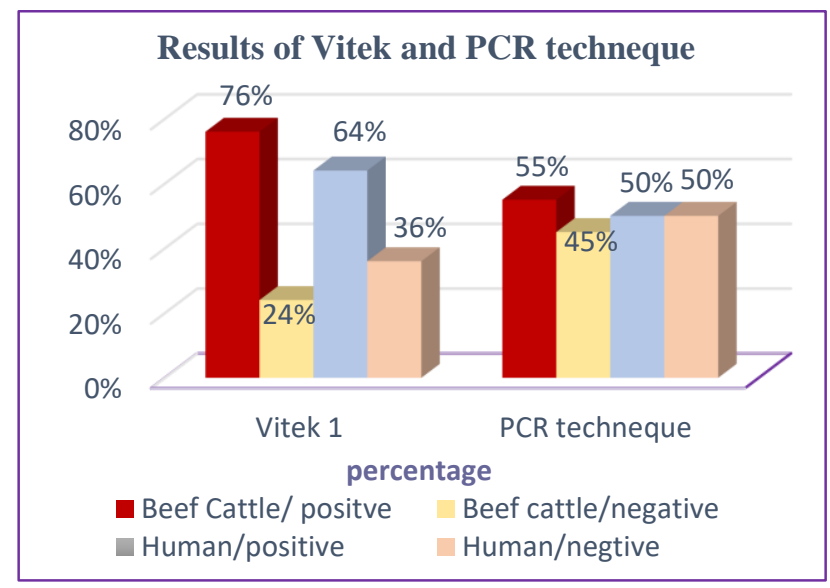

Figure 3: Comparative of $K$. pneumoniae infection by Vitek2 and PCR technique.

\section{Sequencing and phylogenetic analysis}

Two isolates from cattle, and two isolates from human sent for sequencing, then the four sequences submission in NCBI-GenBank database to get accession number codes (MF314450.1, MF314451.1, MF314452.1, and MF314453.1). Respectively, DNA sequencing method was performed for phylogenetic confirmative of $K$. pneumoniae detection, phylogenetic analysis, and zoonotic importance (Figure 4). The total percentage of substitution mutations rates between nucleotide gene sequences (Figure 5).

\section{Discussion}

K. pneumoniae is a cause of life-threatening diseases. However, the organisms have associated with disease occurrence (18). Particularly concerning are reports that $K$. pneumoniae producing bacteria can spread quickly through large geographic regions (19). The human clinical isolates reveal a strong relationship with beef isolates, but it was showed low percentage in some another study such as in beef meat, the prevalence of $K$. pneumoniae isolates was more than human 38 (76\%), $32(64 \%)$ of $K$. pneumonia by VITEK2. Also, it was $21(55 \%), 16(50 \%)$ in PCR results in both beef meat and human respectively. All meat that sold and distributed for use as food - animal production in Iraq. This confined with the result of united state $(20,21)$. Thus, the distribution of $K$. pneumoniae population may reflect that food animal production vs hospital and general community use (22).

In contrast, genetic analysis demonstrates overlap between meat source and clinical $K$. pneumoniae population main strain of human and cattle isolates (MF314450.1), (MF314451.1), (MF314453.1) were related to the two strain, (KP091885.1) Klebsiella pneumoniae strain were isolated from Mauremys mutica from china and (KY471720.1) K. pneumoniae which isolated from water in India, while MF314452.1 that isolated from urine Human were more related to (MF429117.1) which isolated from buffalo milk from china this mean more relationship of strain of human with strains of cattle and the zoonotic relationship between them reveled the dangerous of $K$. pneumoniae that effect human with foodborne product (23).

The increase in infection of urinary tract lead of multidrug resistance with $K$. pneumonia and lead to be more virulence this cause may be mutation in the nucleotide that lead to be more resistance and need to scope on this point to know the reason of frequently infection of urinary tract system (24). 
KP091885.1 Klebsiella pneumoniae strain QX121123 165 ribosomal RNA gene partial sequence MP314453.1 Kebsiella pneumoniae strain KP.HU2 165 ribosomal RNA gene partial sequence - MP314451.1 Kebsiella pneumoniae strain KP.CT2 165 ribosomal RNA gene partial sequence A MP314450.1 Kebsiella pneumoniae strain KP.CT1 165 ribosomal RNA gene partial sequence KY471720.1 Klebsiella pneumoniae strain MK21 165 ribosomal RNA gene partial sequence J)390619.1 Klebsiella pneumoniae strain NEHU.ANSRJ.115 16S ribosomal RNA gene partial sequence

0. 9 N900473.1 Klebsiella pneumoniae strain $S 6916$ S ribosomal RNA gene partial sequence CP026585.2 Klebsiella pneumoniae strain WCHKP649 chromosome complete genome CP024563.1 Klebsiella pneumoniae strain INF278 diromosome complete genome CP024556.1 Klebsiella pneumoniae strain INF164 diromosome complete genome CP024191.1 Klebsiella pneumoniae isolate KSB1 5D chromosome complete genome

24 MF370895.1 Kebsiella pneumoniae strain Y56R 16S ribosomal RNA gene partial sequence MH045825.1 Klebsiella pneumoniae strain WA-1 165 ribosomal RNA gene partial sequence MH071335.1 Klebsiella pneumoniae strain ukmk5 165 ribosomal RNA gene partial sequence

35. WKM108528.1 Klebsiella pneumoniae strain M.pstv.34.3165 ribosoma RNA gene partial sequence MF767573.1 Kebsiella pneumoniae strain QLR10-2 16S ribosomal RNA gene partial sequence KX674052.1 Klebsiella pneumoniae strain 120-1B 16 S ribosomal RNA gene partial sequence

58.29 KM203760.1 Klebsiella pneumoniae subsp. azæenae strain 8k 16S ribosomal RNA gene partial sequence KY471707.1 Klebsiella pneumoniae strain RK10 165 ribosomal RNA gene partial sequence

243. 2 . M9.4F429117.1 Nebsiella pneumoniae strain CAU9543 16S ribosomal RNA gene partial sequence

32.79 [ MP314452.1 Kebsiella pneumoniae strain KP.HU1 165 ribosomal RNA gene partial sequence

— MH119052.1 Klebsiella pneumoniae strain KP.Camel 16S ribosomal RNA gene partial sequence

- MH119051.1 Klebsiella pneumoniae strain KP.Camel 16S ribosomal RNA gene partial sequence CP017994.1 Klebsiella pneumoniae strain P1428 complete genome

\section{CP024838.1 Klebsiella pneumoniae strain CRKP-1215 chromosome complete genome}

0.00 CP027160.1 Klebsiella pneumoniae strain AR 0361 chromosome complete genome

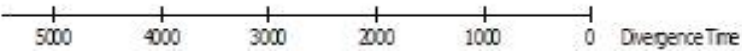

Figure 4: Phylogenetic tree of K. pneumoniae in human and cattle with world strains.

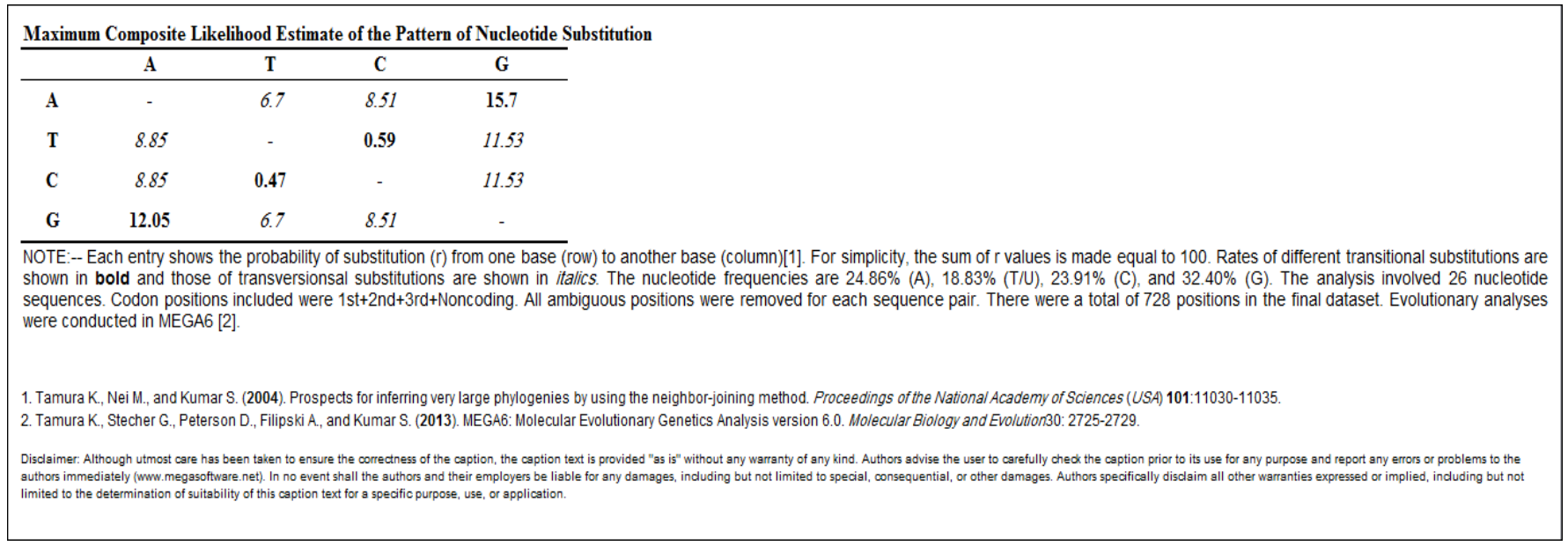

Figure 5: The total percentage of substitution mutations rates between nucleotide gene sequences.

\section{Reference}

1. Kim JK, Chung DR, Wie SH, Yoo JH, Park SW. Risk factor analysis of invasive liver abscess caused by the K1 serotype Klebsiella pneumoniae. Euro J Clin Micro Infect Dis. 2009;28:109-111.

2. Ko WC, Paterson DL, Sagnimeni AJ, Hansen DS, Von Gottberg A. Community-acquired Klebsiella pneumoniae bacteremia: global differences in clinical patterns. Emerg Infect Dis. 2002;8:160-166.
3. Yu VL, Hansen DS, Ko WC, Sagnimeni A, Klugman KP. Virulence characteristics of Klebsiella and clinical manifestations of $K$. pneumoniae bloodstream infections. Emerg Infect Dis. 2007;13:986993.

4. Jong GM, Hsiue TR, Chen CR, Chang HY, Chen CW Rapidly fatal outcome of bacteremia Klebsiella pneumoniae pneumonia in alcoholics. Chest. 1995;107:214-217.

5. Shellito JE, quan Zheng M, Ye P, Ruan S, Shean MK. Effect of alcohol consumption on host release of interleukin-17 during 
pulmonary infection with Klebsiella pneumoniae. Clin Exp Res. 2001;25:872-881.

6. Greenberg SS, Ouyang J, Zhao X, Parrish C, Nelson S. Effects of ethanol on neutrophil recruitment and lung host defense in nitric oxide synthase I and nitric oxide synthase II knockout mice. Clin Exp Res. 1999; 23:1435-1445.

7. Lau HY, Huffnagle GB, Moore TA Host and microbiota factors that control Klebsiella pneumoniae mucosal colonization in mice. Microb Infect Inst Pasteur. 2008;10:1283-1290.

8. Quinton LJ, Nelson S, Zhang P, Happel KI, Gamble L. Effects of systemic and local CXC chemokine administration on the ethanolinduced suppression of pulmonary neutrophil recruitment. Clin Exp Res. 2005;29:1198-1205.

9. Fodah RA, Scott JB, Tam H, Yan P, Pfeffer TL, Warawa JM. Correlation of Klebsiella pneumoniae comparative genetic analyses with virulence profiles in a murine respiratory disease model. PLoS One. 2014;9(9):e107394.

10. Kim SH, Wei CI, Tzou YM, An H. Multidrug-resistant Klebsiella pneumoniae isolated from farm environments and retail products in Oklahoma. J Food Prot. 2005;68:2022-9.

11. Brisse S, Fevre C, Passet V. Virulent clones of Klebsiella pneumoniae: Identification and evolutionary scenario based on the genomic and phenotypic characterization. PLoS One.2009;4:e4982.

12. Ewers C, Stamm I, Pfeifer Y. Clonal spread of highly successful ST15-CTX-M-15 Klebsiella pneumoniae in companion animals and horses. J Antimicrob Chemother. 2014;69:2676-80.

13. Podschun R, Ullmann U. Klebsiella spp. As nosocomial pathogens: Epidemiology, taxonomy, typing methods, and pathogenicity factors. Clin Microbiol Rev. 1998;11:589-603.

14. Laupland KB, Ross T, Pitout JD, Church DL, Gregson DB. Community-onset urinary tract infections: A population-based assessment. Infect. 2007;35:150-3.
15. Quinn PJ, Markey B, Carter ME, Donnelly WJ, Leonard FC. Microbiologia Veterinária e Doenças Infecciosas. Artmed Porto Alegre. 2005. Peoples

16. MacFaddin F. Biochemical tests for identification of medical bacteria. $3^{\text {rd }}$ ed. Philadelphia: The Williams and Wilkins Baltimor; 2000.

17. Price MN, Dehal PS, Arkin AP. FastTree 2-approximately maximumlikelihood trees for large alignments. PLoS One. 2010;5:e9490

18. Villegas MV, Lolans K, Correa A. First detection of the plasmidmediated class A carbapenemase KPC-2 in clinical isolates of Klebsiella pneumoniae from South America. Antimicrob Agents Chemother. 2006;50:2880-2.

19. Navon-Venezia S, Leavitt A, Schwaber MJ. First report on a hyperepidemic clone of KPC-3-producing Klebsiella pneumoniae in Israel genetically related to a strain causing outbreaks in the United States. Antimicrob Agents Chemother. 2009;53:818-20.

20. McGregor JC, Bearden DT, Townes JM. Comparison of antibiograms developed for inpatients and primary care outpatients. Diagn Microbiol Infect Dis. 2013;76:73-9.

21. Saperston KN, Shapiro DJ, Hersh AL, Copp HL. A comparison of inpatient versus outpatient resistance patterns of pediatric urinary tract infection. J Urol. 2014;191(5):1608-13.

22. FDA. Antimicrobials Sold or Distributed for Use in Food-Producing Animals,https://www.fda.gov/.../UserFees/AnimalDrugUserFeeActA DUFA/UCM534243.pdf

23. Davis GS, Price BL. Summary report on Recent Research Examining Links among Klebsiella pneumoniae from Food, Food Animals, and Human Extraintestinal Infections 2016;3(2):128-35

24. Davis GS, Waits K, Nordstrom L. Intermingled Klebsiella pneumoniae populations between retail meats and human urinary tract infections. Clin Infect Dis Off Publ Infect Dis Soc Am. 2015;61(6):892-9. 